\title{
TEN YEARS OF CHANGE IN NEW ZEALAND MANUFACTURING EMPLOYMENT
}

\author{
Richard Willis \\ Victoria University of Wellington
}

\begin{abstract}
Ten years have now passed since New Zealand began the liberalisation and restructuring of its economy. Basically we have gone from a country where a young person could leave school at fifteen and get a low-skilled job in the freezing works of the electrical assembly industry, to one where few such jobs now exist and there is nearly $10 \%$ unemployment. It is now clear that the manufacturing sector has been responsible for about $75 \%$ of the net job loss. This paper takes an overview of the research and data now available to document the specifics of the change in manufacturing employment, focusing on the causes, policies, and the results of the changes, and describes the character of the 'lean, mean' sector which has emerged after the ten years of change.
\end{abstract}

It is fair to say that of all the sectors of the New Zealand economy, manufacturing has been most affected by the restructuring and deregulation policies since 1984 . The fall in manufacturing jobs (over 80,000 1980-1990) explains over $75 \%$ of the net increase in unemployment. Gone are the days when in New Zealand a young person could leave school at 15 and get a reasonable job in the dairy factory, freezing works or the Ford Motor Company. These jobs still exist, but they are dramatically fewer in number and there has been an upgrading in the 'skill level' required.

In 1982 I visited a small factory making a tourist-market product in a small New Zealand rural town. They then employed 15 workers, only three in sales management, distribution or marketing. Today they still employ about 12 workers in production, but the process is far more mechanised, they produce three times the output and their total labour force has doubled, all the increase being in sales, management, distributing and marketing. Now this increase in employment is actually unusual for New Zealand, but this case illustrates the dramatic increase in productivity and the change in the skills and orientation of employment.

The industrial landscapes of our largest cities lie strewn with the deserted monoliths of a by-gone industrial era. In Wellington for example one can view in relatively close proximity in Petone, the former Gear meatworks, the New Zealand Motor Corporation assembly plant, the Ford Motor Company assembly plant, and General Motors: the list could go on to include many smaller firms that have closed or shifted. This period of unprecedented decline in the manufacturing work force (labelled variously as restruc- turing, de-industrialisation, or simply industrial change) stands out against three decades of growth in the industrial work force.

Table 1 shows for example that in the 1950s manufacturing employment increased over $37,100(23.1 \%)$; in the 1960 s it was over 75,000 (a massive $37.9 \%$ ); by the 1970 s it increased another $45,000(16.9 \%)$; but in the 1980 s it declined by over $82,000(-25.9 \%)$.

The obvious question arises: what has produced this cataclysmic change in a relatively short space of time? To answer this question we must examine the historical development of New Zealand manufacturing, and the changing political economy within which it has developed.

\section{New Zealand manufacturing: inefficient, underdeveloped, and overprotected?}

A combination of three factors seemed to ensure the early direction for New Zealand manufacturing. Firstly the isolation from major sources of imports in the 19th century meant that we were forced to develop a wide range of industries given our size and population, at a time when the sailing ship voyage from England to New Zealand took on average 110 days. Secondly the small dispersed nature of the cash-strapped colonial economy meant that rampant laissez-faire capitalism never really flourished, and the government always had to pick up the tab for major investments and regulations. Thirdly the prevailing political culture favoured this anyway. The government came to be looked upon as friend and provider. In this political and cultural soil the welfare state flourished at a uniquely early stage, and it was but a short step to full blown Keynesian 


\begin{tabular}{|c|c|c|c|c|c|c|c|c|c|}
\hline & 1950 & & 1960 & & 1970 & & 1980 & & 1990 \\
\hline Food, Bev., Tob. & 36.3 & & 45.6 & & 60.5 & & 78.0 & & 51.0 \\
\hline Textiles and clothing. & 37.1 & & 39.5 & & 50.4 & & 48.9 & & 25.7 \\
\hline Wood and W.Prod. & 21.1 & & 20.7 & & 21.1 & & 22.8 & & 21.9 \\
\hline Paper and Prod. & 11.6 & & 18.5 & & 27.8 & & 33.4 & & 32.9 \\
\hline Chem. and Petrol. & 9.0 & & 13.4 & & 22.6 & & 28.1 & & 20.4 \\
\hline Non M. Minerals & 7.1 & & 8.8 & & 12.1 & & 10.8 & & 7.8 \\
\hline Base Metals & 1.7 & & 2.1 & & 3.5 & & 8.1 & & 7.6 \\
\hline Fabricated Metal P. & 33.2 & & 45.5 & & 70.8 & & 84.1 & & 66.0 \\
\hline Other Manufacturing. & 3.4 & & 3.6 & & 4.0 & & 4.6 & & 3.5 \\
\hline Total & 160.7 & $23.1 \%$ & $(+37.1)$ & $37.9 \%$ & $(+75.0)$ & $16.9 \%$ & $(+46.1)$ & $-25.9 \%$ & $(-82.6)$ \\
\hline Manufacturing. & & & 197.8 & & 272.8 & & 318.9 & & 236.3 \\
\hline Total Labour Force & 720.6 & & 861.1 & & 1070.9 & & 1266.1 & & 1223.9 \\
\hline
\end{tabular}

Source: Philpott (1990)

economic policies of intervention, regulation, and protection.

Natural isolation meant that the tariff was the main weapon used for industrial protection. This was until the fall in freight costs along with the effects of the Great Depression meant that New Zealand's manufacturing sector was seen to be vulnerable. Import licensing was therefore introduced in 1938, ostensibly to limit imports for balance of payments reasons. But this more absolute form of protection quickly became the accepted way of ensuring the growth of manufacturing employment in New Zealand until the 1980s. Even as late as 1979 Minister of Finance Muldoon restated the traditional view:

It has been suggested that New Zealand should dismantle the system of import licensing which has operated for forty years. I do not subscribe to that view. I have no intention of letting efficient industries go to the wall for the sake of a theory (Wooding 1989:94).

It is interesting that Muldoon had referred to 'efficient' firms. The irony was that many of the regulations governing New Zealand industry had been introduced in the so called Industrial Efficiency Act of 1936 . In reality New Zealand firms were not efficient at all compared to their overseas counterparts. The problem lay in the fact that import licensing was a very absolute form of protection compared with tariffs and therefore New Zealand firms only had to adjust to the demands of local competition, not the international market. This meant that in the period of rapid post-war growth when many advanced economies were shedding industrial jobs in declining industries, upgrading their manufacturing technology, and exporting on a large scale, New Zealand manufacturers remained cosseted in their protected home market without the incentive to change or upgrade to the same extent. Table 2, for example, compares annual average growth rates of output and employment for New Zealand and the Netherlands for the 1960 s.

The general picture that emerges is that in the Netherlands, real value added, expanded faster than employment, productivity increased, as traditional industries began to shed labour, and growth industries to absorb it. New Zealand in the 1960 s presents the picture of a much more immature manufacturing sector. Net output increased more slowly than employment despite some spectacular increases in industries just beginning.

Of course this is not to imply that New Zealand manufacturers were lazy or incapable of increasing their productivity. Rather that the economic environment did not encourage them to do so, being not only heavily protected, but also regulated and heavily taxed. Investigating the theme of regulation the New Zealand planning council came up with a list of nearly 400 acts of Parliament and 1000 associated regulations, which have significant economic effects for New Zealand firms. In addition it is estimated that there were 127 industry tribunals regulating behaviour and 400 official advisory committees, councils and boards. (Economic Monitoring Group 1985: 21)

A good example of this is data provided to the author by the economist in charge of costing at Todd Motors Motor Assemblers in Porirua for the mid 1970s. He showed that in fact the manufacturer could only influence $40 \%$ of the total cost of cars because $60 \%$ of the final price to customers was made up of import duties, sales tax, and various other taxes, see table 3.

Not only was the New Zealand manufacturing sector over regulated, but it was also overprotected. Elkan (1972) calculated that we had the most heavily protected manu- 
Table 2. Annual average growth rates of output and employment in Zealand and the Netherlands 1958-60 to 1968-70 by manufacturing group.

\begin{tabular}{lrrrr}
\hline & \multicolumn{2}{c}{$\begin{array}{c}c \\
\text { Output }\end{array}$} & & \multicolumn{2}{c}{ Employment } \\
S.I.C. Group & Netherlands & N.Z. & Netherlands & N.Z. \\
\hline Food and drink & 4.3 & 7.4 & 0.1 & 2.9 \\
Tobacco & 3.1 & -0.6 & -3.2 & -2.0 \\
Textiles & 2.6 & 3.5 & -3.6 & 4.5 \\
Clothing and Footwear & 1.4 & -1.9 & -1.0 & 0.1 \\
Leather & 1.9 & 2.7 & -1.8 & 3.6 \\
Wood & 9.4 & -2.8 & 0.6 & 1.0 \\
Paper & 8.1 & 1.2 & 2.0 & 6.0 \\
Printing & 6.8 & 1.9 & 2.1 & 4.2 \\
Chemicals & 14.6 & 8.5 & 3.9 & 10.8 \\
Petrol and Coal & 7.2 & 32.8 & 0.7 & 6.2 \\
Rubber & 5.6 & 0.6 & 1.2 & 3.1 \\
Non M. Minerals & 5.3 & -1.3 & 0.0 & 2.8 \\
Base Metals & 10.1 & 10.3 & 3.0 & 13.1 \\
Metal Products & 6.1 & 5.7 & 1.4 & 7.3 \\
Machinery N.E. & 7.2 & 6.2 & 2.3 & 6.2 \\
Machinery E & 7.1 & 5.6 & 2.8 & 9.6 \\
Transport equipment & 2.6 & 14.8 & 0.1 & 4.6 \\
Other & -2.8 & -0.9 & -3.3 & 0.5 \\
Total Manufacturing & 6.8 & 2.3 & & \\
\hline
\end{tabular}

1. Output $=$ value added at 1959 prices.

Sources: Netherlands: U.N. Economic Commission for Europe Structure and Change in European Industry. pp 124-125. New Zealand: N.Z. Official Yearbooks and 1978-79 Manufacturing Census (unpublished) Statistics Dept.

facturing sector in the O.E.C.D., even aknowledging that data on effective rates of protection are notoriously difficult to calculate, especially when import licensing is considered. Table 4 shows that levels of effective protection increased during the 1960 s then fell again up to 1979. but were still high in absolute terms.

The safe operation in a protected home market ensured that by and large the New Zealand manufacturing industry was not export-oriented. Table 5 shows that by 1980 some industry groups had begun to increase exports quite considerably, but in some of the large employment groups such as metal products and machinery, the percentage of total output exported was very small. This is highlighted when one compares similar figures for an export-oriented country like Switzerland. A recent figure from the New Zealand Manufacturers Federation claims that exports rose to about $23 \%$ of total manufacturing output in 1994 .

Now the above analysis is, like all analyses, something of a simplification. Various National Party governments had sought to reduce the coverage of import licenses, but it still basically covered those industries most likely to be affected by foreign competition.

From 1962 to 1978 successive govemments acknowledged the need for a more outward looking posture for
Table 3. The government and efficiency. Costs for a 2000cc Japanese car (late 1970s)

Changes Post 1984

\begin{tabular}{lrl}
\hline Todd Motors Pay & $\$ 2,000$ & \\
Freight and Insurance & $\$ 250$ & \\
Bank and Landing & $\$ 70$ & \\
Duty 45\% & $\$ 900$ & $*$ * Removed \\
& & \\
Landed costs & $\$ 3,120$ & \\
& & \\
NZ Materials & $\$ 1,200$ & \\
Labour/Assembly & $\$ 350$ & \\
Overheads & $\$ 500$ & \\
& & \\
Total direct cost & $\$ 5,270$ & \\
Sales tax & $\$ 2,200$ & $*$ Removed \\
& $\$ 7,470$ & \\
& & \\
Retailer & $\$ 750$ & \\
Freight & $\$ 100$ & \\
Total & $\$ 8,320$ & $*$ * Add G.S.T. \\
& & but lower tax rate
\end{tabular}

Source: Todd Motors 


\section{Table 4. Estimates of the level of effective protection in New Zealand manufacturing.}

\begin{tabular}{lrrr}
\hline Production Group & $\mathbf{1 9 5 6}^{\mathbf{1}}$ & $\mathbf{1 9 6 5}^{\mathbf{2}}$ & $\mathbf{1 9 7 9}^{\mathbf{3}}$ \\
\hline Food, beverages, tobacco & 88.6 & 8.0 & 8.6 \\
Textiles, apparel, leather & 67.6 & 338.8 & 69.2 \\
Wood and wood products & 130.8 & 187.3 & 28.9 \\
Paper printing and publishing & 46.8 & 67.8 & 9.8 \\
Chemicals, petrol, plastics & 21.6 & 24.3 & 48.7 \\
Non M. Minerals & -15.1 & 13.9 & 17.1 \\
Base Metals & -5.8 & 161.8 & 3.7 \\
Metal products and machinery & 560.5 & 251.2 & 64.2 \\
Other manufacturing & 69 & 186.4 & 76.2 \\
\hline Total Manufacturing & $\mathbf{5 0 . 0}$ & $\mathbf{7 3 . 4}$ & $\mathbf{3 6 . 1}$ \\
\hline
\end{tabular}

Sources: ${ }^{1}$ and ${ }^{2}$ Elkan (1972:70, 81-82) ${ }^{3}$ O'Dea (1980:14)

manufacturing, but tended to see this as being fulfilled by attention to export promotion. In this vein various export taxation incentives were introduced meaning that significant numbers of firms began to dabble in exporting if only to get cheap overseas trips. Willis, in a study of 100 engineering firms carried out in 1970 , found that in only $20 \%$ did exports make up more than $20 \%$ of total sales, and for $65 \%$ of firms exports made up less than $10 \%$ of total sales. In addition over $95 \%$ of these firms were exporting mainly to Australia and some $50 \%$ under the provisions of N.A.F.T.A. (Willis 1972). This Australia/New Zealand Free Trade Agreement had begun in 1966 and had paved the way for the closer Economic Relationship which developed later in the 1980 s.

Also there had been far-sighted government ministers who had realised the importance of industrial change. Brian Talboys for example wrote in 1980

Successful countries do not cling to outmoded or uncompetitive industries or technologies. They allow them to decline whether through the invisible hand of the market place, or the invisible boot of the planning agency in countries like Japan - and employ their resources elsewhere. The process goes by different

Table 5. Swiss Exports of Main Manufacturing Industries: 1970s

\begin{tabular}{llr} 
Branch & $\begin{array}{l}\text { Exports as \% \% of exports } \\
\text { total output }\end{array}$ \\
\hline Engineering & 80 & 43.2 \\
Chemicals & 90 & 19.6 \\
Clocks and watches & 90 & 8 \\
Textiles and clothing & 80 & 7.4 \\
\hline
\end{tabular}

Source: Economist survey, 1979. names, revitalization, upgrading, rebuilding or restructuring - but the aim is basically the same (quoted in Willis 1982: 78).

Towards the end of the 1970 s this view began to hold sway and build upon some earlier landmark decisions such as recommendation 209A from the National Development Conference held in May 1969.

The manufacturing sector should be accorded a level of protection sufficient to promote steady industrial development, increasing manufactured exports and full employment. This level of protection however should be such as to encourage competition, efficiency and reasonable prices to other sectors and to consumers, and should also have regard to consumer choice and variety. It accordingly recommended that the system of protection should be flexible, that import licensing should be replaced by tariffs as the main measure of protection, and that this transition should be carried out in accordance with a clearly defined programme and within a reasonable time (quoted in Wooding 1989: 92).

Therefore ten years after the National Development Conference (N.D.C.) had passed this recommendation the National government embarked on what Wooding calls 'A Cautious Liberalisation' (Wooding 1989: 94) This liberalisation included a wider free trade agreement with Australia, import license tendering, the industries study programme, and the recognition by government of the need to reduce the unevenness of levels of manufacturing protection.

The Industries Studies Programme in particular was interesting because of the political furore it caused; in retrospect it was rather tame compared to what Roger Douglas was to introduce later. Back in 1978 the Tariff Review Committee had identified eleven industry groups for fur- 


$\begin{array}{ll}\text { Deregulation of entry licensing in industry } & 1984+ \\ \text { Partial deregulation of occupational licensing } & 1985+ \\ \text { removal of other operating barriers in industry } & 1984+ \\ \text { Removal of price control } & 1984-88 \\ \text { Removal of import licensing } & 1984-88 \\ \text { Significant decrease in import tariffs } & 1985-92 \\ \text { Revision of town and country planning } & 1987 \\ \text { Revision in role of producer marketing boards } & 1987+ \\ \text { Abolition of many quangos and quasi-government organisations } & 1987 \\ \text { Removal of financial controls (interest rate ceiling, } & \\ \text { reserve ratio requirements, priorities for various sectors) } & 1984-86 \\ \text { Removal of foreign exchange controls } & 1984 \\ \text { Liberalization of foreign direct investment } & 1985 \\ \text { Floating of the exchange rate } & 1985 \\ \text { Revision of corporate, personnel, and direct taxation } & 1986-88 \\ \text { Corporatization of stage trading activities } & 1986+ \\ \text { Programme of sale of state assets } & 1987+ \\ \text { Review of education and health provision } & 1988+ \\ \text { Removal of monopoly rights on state trading } & 1986 \\ \text { Review of competition regulation: Commerce Act/Bank Act/ } & \\ \quad \text { Securities Act/Companies Act } & 1986-89 \\ \text { Deregulation of transport sector } & 1983-88 \\ \text { Deregulation of financial services sector } & 1986 \\ \text { Partial deregulation of energy sector } & 1986+ \\ \text { Removal of concessions for favoured investment (e.g. R\&D) } & 1984+ \\ \text { Removal of concessions for favoured sectors (agriculture, export sectors) } & 1984+ \\ \text { Establishment of closer economic relations with Australia } & 1983+ \\ \text { Reorganisation of core government departments } & 1987+ \\ \text { Reform of local government } & 1989+ \\ \text { Deregulation of ports and waterfront work } & 1989 \\ \text { Removal of shop trading hours restrictions } & 1989 \\ \text { Corporatisation of some local authority trading activities } & 1989 \\ \text { Partial deregulation of shipping } & 1990 \\ \text { Resource management law reform } & 1990 \\ \text { Source: Savas } & \end{array}$

Source: Savage and Bollard,(1990)

ther study because of their need for continuing high assistance. Some of these studies were to be carried out by government departments and others by the I.D.C. (Industries Development Commission), called the Industrial Destruction Commission by the Unions. In effect the Industries Studies Programme was the last attempt at 'planned restructuring' before the market realities of Roger Douglas after 1984. In fact the impact of the Industries Studies Programme was largely obliterated by the wider changes needed under the C.E.R. arrangement with Australia (signed 1982), just as the programme of trade liberalisation under C.E.R. was taken over by more general liberalisation policies post 1984.

In summary the point being made here is that some deregulation/liberalisation had begun prior to 1984 through the Industries Studies Programme, the review of licensing, the C.E.R. agreement and other indirect initiatives such as the deregulation of the freight transport industry. But change was still slow and much of this so called liberalisation took place at the same time as Muldoon's National government imposed a wages and price freeze to try and curb inflation. The real changes were still to come.

\section{What happened after 1984?}

Savage and Bollard detail three types of liberalisation affecting the New Zealand economy post 1984 (Savage and Bollard 1990: 37-38).

Firstly there was macro-economic liberalisation. This is basically those policies not designed to be industry specific but have impacted on firms by altering the prices of inputs or outputs, or by directly influencing the economic environment in which firms operate.

Secondly there were the reductions in protection and subsidies including the phase out of import licensing, moves toward lower tariffs, and withdrawal of various production subsidies both implicit and explicit.

The third major type of change is deregulation. This has 
Table 7. Change in manufacturing employment in New Zealand 1987-93.

\begin{tabular}{|c|c|c|c|c|}
\hline Industry & 1987 & 1993 & Actual Change & $\%$ Change \\
\hline Meat processing & 36640 & 27861 & -9779 & -24.0 \\
\hline Dairy products & 8035 & 7616 & -419 & -5.2 \\
\hline Other foods & 24075 & 23237 & -838 & -3.4 \\
\hline Beverages and tobacco & 4611 & 2671 & -1940 & -42.1 \\
\hline Food, Bev. and Tobacco & 73361 & 61385 & -11976 & -16.3 \\
\hline Textiles & 13988 & 10552 & -3436 & -24.6 \\
\hline Apparel and footwear & 26862 & 16818 & -10044 & -37.4 \\
\hline $\begin{array}{l}\text { Textiles, Clothing } \\
\text { and Footwear }\end{array}$ & 40850 & 27370 & -13480 & -33.0 \\
\hline $\begin{array}{l}\text { Wood Processing } \\
\text { and Prod. }\end{array}$ & 26560 & 21729 & -4831 & -18.2 \\
\hline Paper and paper products & 10637 & 9033 & -1604 & -15.1 \\
\hline Printing and publishing & 19278 & 16895 & -2383 & -12.4 \\
\hline $\begin{array}{l}\text { Paper, Printing } \\
\text { and Publishing }\end{array}$ & 29915 & 25928 & -3987 & -13.3 \\
\hline Industrial chemicals & 5079 & 4614 & -465 & -9.2 \\
\hline Other chemicals & 7486 & 5904 & -1582 & -21.3 \\
\hline Petroleum refining & 1082 & 759 & -323 & -29.9 \\
\hline Petrol and coal products & 570 & 195 & -375 & -65.8 \\
\hline Rubber products & 3727 & 1923 & -1804 & -48.4 \\
\hline Plastic products & 7769 & 7025 & -744 & -9.6 \\
\hline Chemicals etc. & 25713 & 20420 & -5293 & -20.6 \\
\hline Non M. Metals & 9708 & 6355 & -3353 & -34.5 \\
\hline Basic Metal Products & 6599 & 6104 & -495 & -7.5 \\
\hline Fabricated metal prod. & 27446 & 19459 & -7987 & -29.1 \\
\hline Machinery & 19032 & 15448 & -3584 & -18.8 \\
\hline Electrical machinery & 13445 & 10226 & -3219 & -23.9 \\
\hline Transport Equipment & 21382 & 7816 & -13566 & -63.4 \\
\hline Professional Equipment & 1313 & 1008 & -305 & -23.2 \\
\hline $\begin{array}{l}\text { Fabricated Metals } \\
\text { and Mach. }\end{array}$ & 82618 & 53957 & -28661 & -34.7 \\
\hline Other Manufacturing & 4739 & 4107 & & \\
\hline Total Manufacturing & 300063 & 227354 & -72709 & -24.3 \\
\hline
\end{tabular}

Source: New Zealand Business Activity Statistics 1987-93.

taken various forms including the removal of price controls, the liberalisation of competition laws and the corporatisation/privatisation of government trading enterprises. Table six below is Savage and Bollard's summary of the major economic liberalisation measures 1984-1990.

\section{The results of change.}

There is little doubt about the magnitude of the changes. Table 1 has already shown a net loss of 82,000 manufac- turing jobs in the 1980 s - nearly $26 \%$ of the manufacturing work force. Declines were particularly severe in textiles and clothing (-48\%), and food, beverages and tobacco ($35 \%$ ) while the losses were least severe in wood products $(-4 \%)$, paper and printing $(-2 \%)$, and base metals $(-6 \%)$.

The publication of the New Zealand Business Activity Statistics for the first time in 1987 provided another useful data base from which to assess the changes in employment and output. Table 7 shows changes in employment 1987 - 
Table 8. Changes in employment and number of enterprises by size group in New Zealand manufacturing 1987 - 1994.

\begin{tabular}{lllllll}
\hline Size Groups & $\mathbf{0 - 5}$ & $\mathbf{6 - 9}$ & $\mathbf{1 0 - 4 9}$ & $\mathbf{5 0 - 9 9}$ & $\mathbf{1 0 0 +}$ & TOTAL \\
\hline $\begin{array}{l}\text { Employment change 1987-1992 } \\
\text { Actual }\end{array}$ & 2479 & -1738 & -11746 & -7028 & -50449 & -68473 \\
$\begin{array}{l}\text { Percentage change } \\
\text { Employment change 1992-1994 }\end{array}$ & $10.10 \%$ & $-10.60 \%$ & $-18.30 \%$ & $-22.00 \%$ & $-31.80 \%$ & $-23.10 \%$ \\
$\begin{array}{l}\text { Actual } \\
\text { Percentage change }\end{array}$ & 1211 & 1271 & 4066 & 2844 & 8057 & 17419 \\
& $4.50 \%$ & $8.70 \%$ & $7.80 \%$ & $11.50 \%$ & $7.40 \%$ & $7.70 \%$ \\
Enterprises change 1987-1992 & & & & & & \\
$\begin{array}{l}\text { Actual } \\
\text { Percentage change }\end{array}$ & 1919 & -226 & -516 & -101 & -125 & 951 \\
& $18.20 \%$ & $-10.00 \%$ & $-16.30 \%$ & $-22.20 \%$ & $-28.20 \%$ & $5.60 \%$ \\
Enterprises Change 1992-1994 & & & & & & \\
$\begin{array}{l}\text { Actual } \\
\text { Percentage change }\end{array}$ & 1489 & 253 & 259 & 41 & 28 & 2070 \\
& $12.00 \%$ & $12.40 \%$ & $9.80 \%$ & $11.60 \%$ & $8.80 \%$ & $11.60 \%$ \\
\hline
\end{tabular}

Source: Business Activity Statistics 1987-92/93.

1993 from this data base, enabling a more detailed industrial breakdown than Philpot's data in Table 1. Here again the worst and best performers are worth commenting upon. The biggest losers in percentage terms were petrol and coal products $(-65.8 \%)$, transport equipment $(-63.4 \%)$, rubberproducts $(-48.4 \%)$, beverages and tobacco $(-42.1 \%)$, and apparel and footwear $(-37.4 \%)$. By far the best performers were dairy products $(-5.2 \%)$ and other foods ($3.4 \%)$.

There is little doubt from the above data that massive changes have taken place in manufacturing employment and that changes to the macro-economic environment, and industry specific protection are obviously involved. One interesting aspect of change is that it has impacted differentially on different sizes of firms and business enterprises. Table 8 shows data for different size categories of manufacturing activity units and several conclusions become apparent.

1. That the fall in manufacturing employment was greatest between 1984 and 1992 and it hit the larger enterprises hardest; employment fell by over $30 \%$ in the $100+$ size category.

2. Even at the time of greatest job loss the small 0-5 person enterprises were still increasing employment.

3. The situation has improved considerably for the period February 1992 to February 1994, with all size groups incresing employment.

4. The same differences by size category emerge in changes in the number of manufacturing enterprises 1987-1992, with only the 0-5 group increasing enterprise numbers; all size groups have increased enterprise numbers 19921994.

5. Despite the growing number of very small manufactur- ing businesses it is the larger enterprises which still provide most of the employment, for example enterprises of more than 50 employees account for $60 \%$ of total employment but only $3.7 \%$ of enterprises.

\section{The regional impact of manufacturing change.}

While the absolute decline in manufacturing employment has been dramatic and absolute across all industry groups it has not been geographically even. Table 9 shows that the northern part of the South Island has held its small share of manufacturing jobs very well, and of the larger regions Waikato has done the best. This may reflect the efforts of a buoyant dairy industry since 1988 , a possible cause which is reinforced by the fact that Taranaki's rate of decline is also better than most other regions. Of the metropolitan manufacturing centres Canterbury does best and Wellington worst. Wellington's poor performance may be attributed partly to its dependence on large enterprises in certain key industries which have suffered badly. The motor vehicle assembly industry being a classic example.

It also needs to be remembered that because Wellington's exposure and dependence on manufacturing jobs is less than Auckland's or Canterbury's, the impact of this high rate of decline in industrial employment has impacted less heavily on overall jobs and unemployment.

\section{The impact on particular industries - case study: automobile assembly.}

As indicated above, some industries have been more adversely affected by industrial restructuring. In table 7 
Table 9. Regional change in New Zealand manufacturing 1987-1993. Regions ranked from best to worst by percentage change in employment.

\begin{tabular}{lrr}
\hline Region & $\begin{array}{l}\text { Absolute } \\
\text { Change }\end{array}$ & $\begin{array}{l}\text { Percentage } \\
\text { Change }\end{array}$ \\
\hline Marlborough & 3 & 0.1 \\
Tasman/Nelson & -5 & -0.1 \\
Waikato & -1068 & -5.4 \\
Taranaki & -1495 & -16.6 \\
Hawkes Bay & -2399 & -19.1 \\
Canterbury & -7997 & -19.2 \\
Southland & -2145 & -20.0 \\
Bay of Plenty* & -3177 & -22.5 \\
& & \\
National average & -71148 & -23.7 \\
& & \\
Manawatu* & -4087 & -24.5 \\
West Coast & -555 & -25.9 \\
Auckland & -28628 & -26.5 \\
Otago & -4093 & -28.0 \\
Northland & -1912 & -28.2 \\
Gisbome & -981 & -31.1 \\
Wellington* & -10312 & -33.1 \\
\hline
\end{tabular}

Source: Business Activity Statistics 1987-1992.

* Estimates derived from former local government regions.

we saw that the transport equipment manufacturing industry had the highest rate of decline of any three digit industrial group. In retrospect this is hardly surprising given the level of protection and intervention in this industry: As Douglas Greer said:

An auto-assembly industry in New Zealand is essentially artificial. That is to say, its existence is dependent on the assistance regime established and maintained by

Table 10. Automobile Assembly Industry Profile

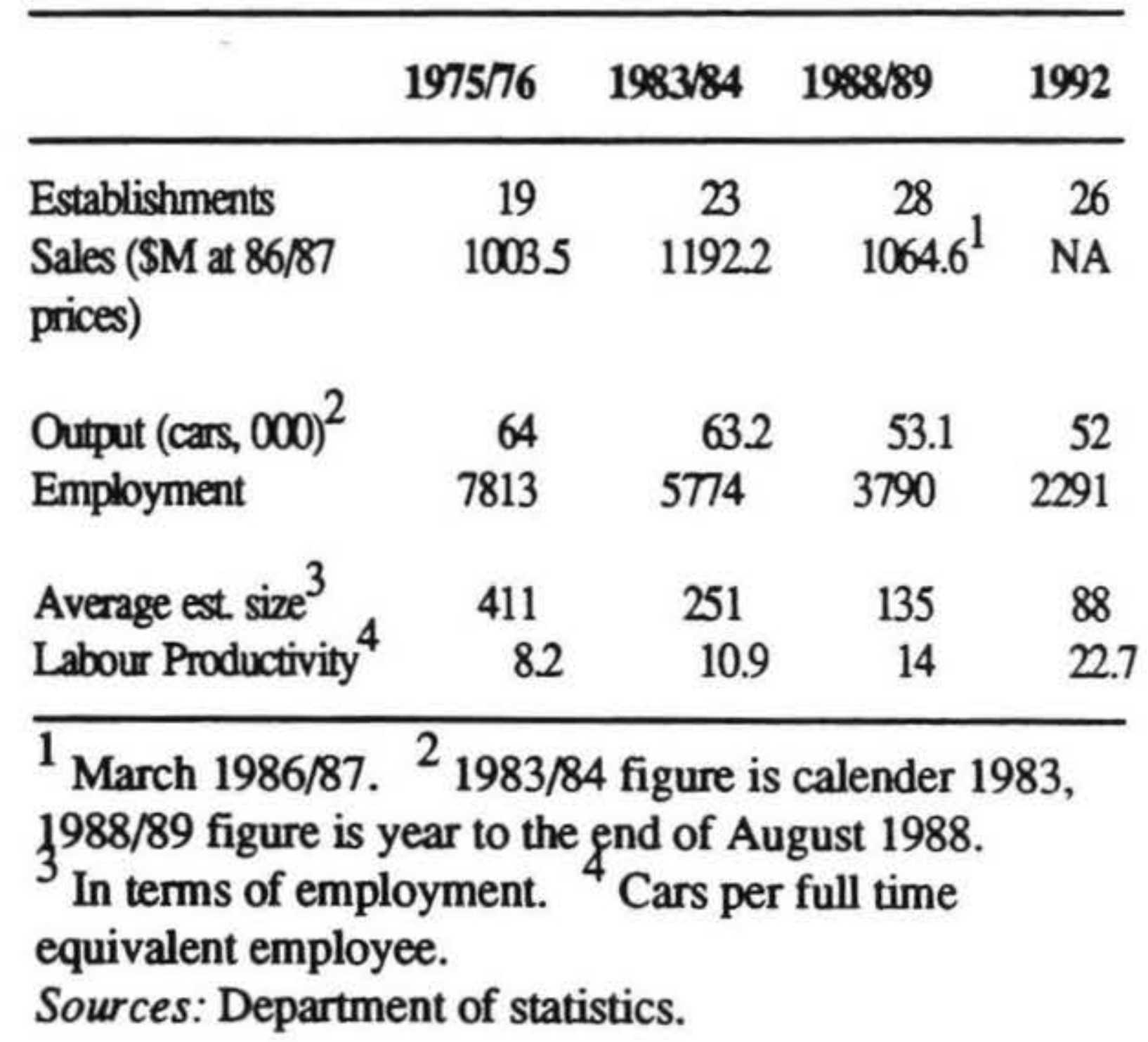

government (Greer 1990: 107).

He went on to say;

the cost of landing a fully assembled new car on the dock of Auckland is barely more than the cost of a knocked down kit in need of assembly by New Zealand labour. Thus it is somewhat inconsistent to say (as was said in the 1984 industrial plan) that despite greatly reduced protection it is the governments intention to retain the assembly sector but to have it efficient. It simply cannot be efficient by world standards; without substantial protection it would simply not exist (Greer 1990: 107).

In fact rationalisation in the motor assembly industry has been going on for some time even before 1984. As table 10 shows. The numbers of establishments actually increased through the 1980s but employment fell away dramatically, and labour productivity in terms of numbers of cars per employee also increased dramatically.

The initial round of changes were ushered in with the 1984 Motor Vehicle Industry Plan which removed import licenses for the CKD (Completely Knocked Down) unassembled vehicles, expanded the market for CBU (Completely Built Up) vehicles, reduced tariffs, abolished some sales taxes and removed hire purchase controls.

In 1987 as part of the Closer Economic Relation negotiation with Australia, and as part of general deregulation policy, the plan was revised and the deregulation and abolition of protection processes sped up.

Table 11 shows the eight plants that have closed since 1984 and table 12 gives the remaining automotive assembly plants as of 1994.

The closures also took place alongside, and in some cases associated with a change in ownership structures. This

Table 11. Auto Assembly Plants that have Closed Since Implementation of the 1984 Plan

\begin{tabular}{ll} 
Company & Plant Location \\
\hline Daihatsu NZ & Te Awamutu \\
Ford Motor Co. of NZ & Lower Hutt \\
Mazda Motors of NZ & Otahuhu \\
Motor Holdings Ltd. & Otahuhu \\
& Waitara \\
NZ Motor Corp. (Honda) & Auckland \\
Nissan & Otahuhu \\
Suzuki & Wanganui \\
General Motors & Upper Hutt (Car Plant) \\
\hline
\end{tabular}

Source: Greer 1990: p110 
Table 12. Remaining Automobile Assembly Plants in New Zealand 1989

\begin{tabular}{ll}
\hline Company & Plant Location \\
\hline General Motors & Upper Hutt (Truck Assembly) \\
Honda & Nelson \\
Mitsubishi & Porirua \\
Nissan & Wiri \\
Toyota & Thames (Passenger) \\
& Christchurch (Commercial) \\
VANZ (Mazda/Ford) & Sylvia Park (Commercial) \\
& Manakau City (Passenger) \\
\hline
\end{tabular}

Source: Greer 1990: p111.

was mainly that Japanese suppliers who had previously left local assembly to New Zealand agents now bought into the assembly business themselves, including Honda, Mitsubishi, and Nissan. Their buy-outs ushered in new manufacturing standards and work-place methodologies such as the celebrated 'Nissan Way' of manufacture.

There is little doubt that as a result of deregulation, lowering of protection, vertical integration, new labour relations and ownership changes, the New Zealand motor assembly industry has become much more efficient, that is in the narrowest sense of producing its output with the lowest cost of inputs. However the industry can never become efficient in the broader sense of international competition because of its small scale. It is common knowledge for example that some plants in Japan produce enough cars to satisfy the whole New Zealand market for all vehicles. The nation must therefore make ultimate decisions on whether it will keep the tariffs in order to protect the remaining assembly plants and the 2,300 jobs in New Zealand.

This raises an interesting point that despite the massive shedding of jobs New Zealand manufacturing still has quite high levels of protection. If we compare ourselves with Australia for example, using some selected measures of protection, what becomes clear from table thirteen is that despite greater publicity given to the restructuring process in New Zealand our overall level of industrial protection is still higher than Australia.

The removal of protection began much earlier in Australia, the process of structural adjustment was more gradual and firms had a longer time to adjust to new policy environments. Also import licensing was abolished 20 years earlier in Australia. This has contributed to a kind of 'stored up' effect of postponing change in New Zealand. This thesis is reinforced by looking at longer term comparisons between Australia and New Zealand. Table fourteen illustrates the fact that the cumulative loss of employment has been greater in Australia where as the largest single intercensal loss has been in New Zealand in the last five years.

\section{What is happening today}

From the above analysis it would be possible to conclude that all was doom and gloom in New Zealand manufacturing. In many ways this couldn't be further from the truth. The sector has definitely turned the corner and most indicators look good for the next year or so. Basically it appears that those businessmen that have survived restructuring, or set up since, are now much more lean and mean and ready to face the new competitive environment of the 1990 s.

Table fifteen shows the trends in key ratios for New Zealand manufacturing since the September quarter 1990 , and the turnaround is evident. While the level of export growth has levelled off this is compensated for by growth in domestic sales as the New Zealand economy begins to grow again. Both hours worked and employment began to grow for the first time since the mid 1980 s with the sector creating 23,300 equivalent fulltime jobs in 1993. Most dramatic and encouraging of all was the increase in investment, particularly in new plants and machinery.

Table 13. Comparison of selected measures of protection

\begin{tabular}{lrc}
\hline Measure & Australia & New Zealand \\
\hline Items free of tariffs (1987) \% & 37 & 49 \\
Items below 15\% (1987) \% & 84.4 & 67 \\
Average level of industry tariffs dutiable & 25.2 & 27.5 \\
(mid-1980s) Total & 12.6 & 16.3 \\
Effective rates of assistance for manufacturing & $25 \%$ & $39 \%$ \\
$1981 / 82$ & $16 \%$ & $19 \%$ \\
$1989 / 90$ & $31 \%$ & $69 \%$ \\
& & \\
Metal products & $18 \%$ & $34 \%$ \\
$1981 / 82$ & & \\
\hline
\end{tabular}

Source: Duncan Lattimore and Bollard (1992) 
Table 14.Longer term employment change in Australia and New Zealand manufacturing 1971-1991.

\begin{tabular}{lll}
\hline $\begin{array}{l}\text { Full-time equivalents } \\
\text { (In 000) }\end{array}$ & Australia & New Zealand \\
\hline 1971 & 1304 & 282 \\
\% change 1971-76 & $-8.3 \%$ & $9.6 \%$ \\
1976 & 1195 & 309 \\
$\%$ change 1976-81 & $-1.3 \%$ & $-0.6 \%$ \\
1981 & 1180 & 306 \\
$\%$ change 1981-86 & $-13.1 \%$ & $-2 \%$ \\
1986 & 1052 & 300 \\
$\%$ change 1986-91 & $-8.4 \%$ & $-20.6 \%$ \\
1991 & 963 & 238 \\
\% change 1971-91 & $-26.2 \%$ & $-15.6 \%$ \\
\hline
\end{tabular}

Sources: Australia- A.B.S. Yearbook 1991; New Zealand - Philpott 1990.

The above data along with the general euphoria about the strength of the economy and economic growth in New Zealand would lead one to believe that the economy is finally getting out of what Franklin calls the "commodity trap' - an export-led economy with an over dependence on commodity exports for which the elasticities of demand tend to be low or fluctuating. This leads to large fluctuations in export earnings which is obviously detrimental to both individual producers and the country as a whole. Some data on this front are encouraging for example the latest Manufacturers Federation Survey stresses the growth of what they call 'Elaborately Transformed Manufacturers'.

The composition of manufacturing exports is moving increasingly towards elaborately transformed manufacturers (ETMs). This group of products which incorporate a high level of domestic design and value added has been growing at a substantially faster rate than other manufactured exports for some 18 months. The major force behind the export expansion of ETMs is coming from the engineering sector. (New Zealand Manufacturers Federation 1994: 3)
However when total exports are examined in more detail the trends are not so good. Table sixteen shows the breakdown of New Zealand merchandise exports 19901993. What is clear is that exports increased by over $\$ 3.8$ billion in that period but that over $75 \%$ of this increase was contributed by commodity groups - meat, fish, dairy products, forest products, wool, iron and steel, and aluminium. Now admittedly more of these sectors output are further processed than previously - dairy products for example are now much more value added. But some huge increases came from outright commodities like sawn timber and logs -over $\$ 700$ million added $1990-1993$. It is clear that the price has already begun to fall and these huge increases will not be sustained.

Further disturbing evidence is provided by Kreigsmann in a 1994 briefing paper to the New Zealand Manufacturers Federation. He stresses the importance of increasing the value added content of New Zealand's production but shows that while value added content has gone up in nominal terms, in real terms it has shrunk considerably during the last decade (Kreigsmann: 1994: 11); see figure one.

\section{Conclusion}

The New Zealand manufacturing sector suffered a massive shakeout of employment during the late 1980s. In the last three years some of that employment has begun to return wiht manufacturing leading the way in lowering unemployment in New Zealand. There is some case-study evidence which shows that these new jobs are different from the low-skilled process workers characteristic of the old heavily protected pre-1984 manufacturing regime. However the trade statistics are rather contradictory in being able to show whether New Zealand has indeed undergone some kind of structural transformation to develop a more mature manufacturing sector not so dependent on processing commodities and exporting goods more dependent on price rather than high value, research and development.

\section{Future research}

More research is needed at the firm level to examine precisely what sort of manufacturing jobs are being created in New Zealand, where the shortages are and what

Table 15. Trends in key ratios for NZ Manufacturing. (\% change real Value)

\begin{tabular}{llllll}
\hline Year ended & Sep-90 & Sep-91 & Sep-92 & Sep-93 & Jun-94 \\
\hline Exports & 3 & 8.9 & 11.9 & 5.3 & 12.8 \\
Domestic Sales & -1.6 & -11 & 2 & 8.6 & 5.0 \\
Total sales & -0.7 & -7.3 & 4.3 & 7.8 & 6.7 \\
Hours worked & -1.5 & -7.1 & -0.9 & 5.6 & 8.0 \\
Full time employment & N.Av. & -5.6 & -4.6 & 3.4 & 5.6 \\
Investment & -5.1 & -24.6 & -13.3 & 34.8 & 25.2 \\
\hline
\end{tabular}

Source: NZ Manufacturers Federation (1994). 
Table 16. Contribution to New Zealand exports 1990-93. (Million \$NZ: June years)

\begin{tabular}{|c|c|c|c|c|}
\hline Group & 1990 & 1993 & $\begin{array}{l}\text { Change } \\
\text { Actual }\end{array}$ & $\%$ \\
\hline $\begin{array}{l}\text { Live Animals } \\
\text { Beef and veal } \\
\text { Lamb and mutton } \\
\text { Total meat }\end{array}$ & $\begin{array}{l}193.7 \\
1091.6 \\
1093.5 \\
2319\end{array}$ & $\begin{array}{l}172.1 \\
1418.7 \\
1389 \\
3057.5\end{array}$ & $\begin{array}{l}-21.6 \\
327.1 \\
295.5 \\
748.5\end{array}$ & $\begin{array}{l}-11.1 \\
30 \\
27 \\
32.3\end{array}$ \\
\hline $\begin{array}{l}\text { Fish } \\
\text { Squid etc. } \\
\text { Crustaceans }\end{array}$ & $\begin{array}{l}503.7 \\
108.4 \\
89.4\end{array}$ & $\begin{array}{l}807.8 \\
140.6 \\
114.6\end{array}$ & $\begin{array}{l}304.1 \\
32.2 \\
25.2\end{array}$ & $\begin{array}{l}60.4 \\
29.7 \\
28.2\end{array}$ \\
\hline $\begin{array}{l}\text { Milk Cream Yoghurt } \\
\text { Butter } \\
\text { Cheese } \\
\text { Total Dairy }\end{array}$ & $\begin{array}{l}998.4 \\
710.5 \\
341 \\
2066.9\end{array}$ & $\begin{array}{l}1352.9 \\
796.5 \\
497.9 \\
2666.2\end{array}$ & $\begin{array}{l}354.5 \\
86 \\
156.9 \\
\mathbf{5 9 9 . 3}\end{array}$ & $\begin{array}{l}35.5 \\
12.1 \\
46 \\
29\end{array}$ \\
\hline Sausage casings & 105.5 & 122.9 & 17.4 & 16.5 \\
\hline $\begin{array}{l}\text { Timber and logs } \\
\text { Wood products } \\
\text { Pulp } \\
\text { Paper and products } \\
\text { Total Forest }\end{array}$ & $\begin{array}{l}402.4 \\
207.5 \\
387.2 \\
352.1 \\
\mathbf{1 3 6 1 . 2}\end{array}$ & $\begin{array}{l}1145.9 \\
336.3 \\
352.8 \\
429.2 \\
2277.6\end{array}$ & $\begin{array}{l}743.5 \\
128.8 \\
-34.4 \\
77.1 \\
916.4\end{array}$ & $\begin{array}{l}704.7 \\
62.1 \\
-8.9 \\
21.9 \\
67.3\end{array}$ \\
\hline $\begin{array}{l}\text { Books and papers } \\
\text { Wool } \\
\text { Carpets etc. } \\
\text { Textiles and Apparel } \\
\text { Stones and Jewellery } \\
\text { Iron and steel } \\
\text { Alu. and products } \\
\text { Machinery and appliances } \\
\text { Electrical Products } \\
\text { Re. Exports }\end{array}$ & $\begin{array}{l}32.5 \\
1315.9 \\
88.3 \\
86.4 \\
95.1 \\
328.7 \\
742 \\
377 \\
227.2 \\
638.9\end{array}$ & $\begin{array}{l}32.3 \\
900.8 \\
71.6 \\
211.4 \\
267 \\
433.4 \\
659.8 \\
496.6 \\
334.8 \\
\mathbf{7 3 0 . 3}\end{array}$ & $\begin{array}{l}-0.2 \\
-415.1 \\
-16.7 \\
125 \\
171.9 \\
104.7 \\
-82.2 \\
119.6 \\
107.6 \\
91.4\end{array}$ & $\begin{array}{l}-0.6 \\
-31.5 \\
-18.9 \\
144.6 \\
180.6 \\
31.9 \\
-11.1 \\
31.7 \\
47.3 \\
14.3\end{array}$ \\
\hline Total Merchandise & 15163.5 & 19006.2 & 3842.7 & 25.3 \\
\hline
\end{tabular}

$75.9 \%$ (Commodities) of increase $=$ Meat $/$ fish $/$ wool $/$ dairy $/$ forest $/$ alu .

$9.1 \%$ (Manufactures) $=$ Textiles/apparel/machinery .

implication this has for the education and training system. We need to know for example whether the 20,000 or so new manufacturing jobs created in the last two years are merely the result of temporary staff being taken on at minimum pay rates under the climate created by the Employment Contracts Act; or are there genuine new long-term positions arising demanding new skills, an updated apprenticeship system and genuine career paths for school leavers?

\section{References}

Crossland, N. 1979 The Everlasting League - A survey on Switzerland Economist 3-9 February, London.

Department of Statistics 1993 New Zealand Business Activity Statistics.

Duncan, I., and Lattimore, R. and Bollard, A. 1992 Dismantling the Barriers: Tariff policy in New Zea-
Figure 1. Real value added in percentage of real production, New Zealand manufacturing

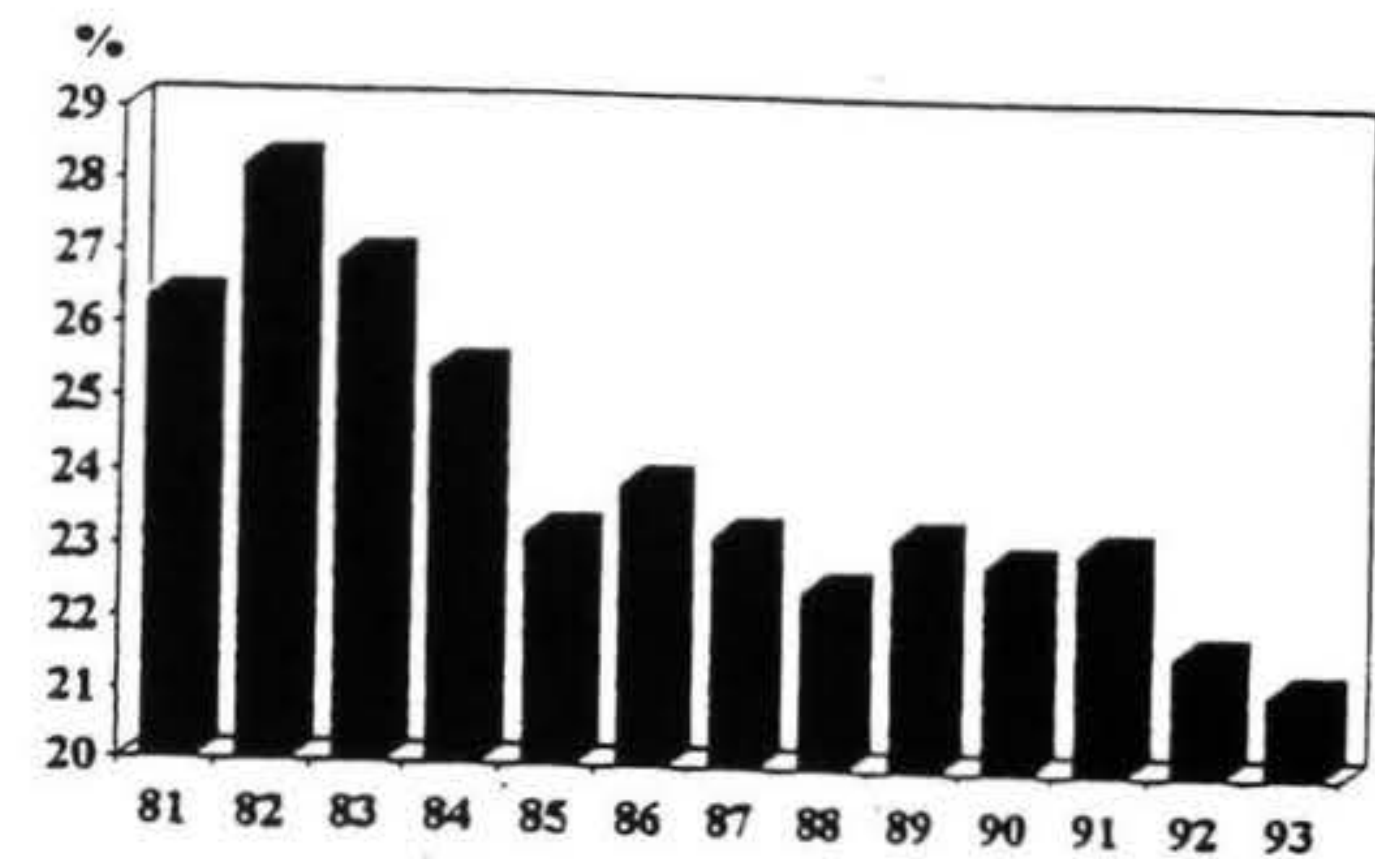


land. NZIER Research Monograph 57.

Economic monitoring Group, NZ Planning Council 1984 Foreign exchange constraints, export growth and overseas debt.

Elkan, P.G. 1972 Industrial Protection in New Zealand 1952-1967. NZ Institute of Economic Research Technical Memorandum No. 15.

Greer, D. 1990 The Automobile Assembly Industry In Savage, J., and Bollard, A. (eds) Turning it around closure and revitalisation of New Zealand industry. Oxford University Press, Auckland.

Kay, J. 1990 The impact of industrial restructuring on manufacturing firms in Levin. Unpublished MA Thesis V.U.W. Geography Department.

Kreigsmann, K.P. 1994 Recent Performance and Outlook for Manufacturing Briefing Paper to the New Zealand Manufacturers Federation May 31.

NewZealand ManufacturersFederation 1994 Trustbank survey of New Zealand Manufacturing (carried out by BE.R.C.) September Quarter 1993.

O'Dea, D.T. 1980 Protection and Unemployment. Address to the 22nd AGM of the NZ Institute of Economic Research, Wellington.

Philpott, B. 1990 A consistent data base of sectoral employment 1950-1990. Research project on Economic Planning Internal Paper 223, Victoria University.

Savage, J., and Bollard, A. (eds) 1990 Turning it Around - Closure and Revitalisation in New Zealand Industry. Oxford University Press, Auckland.

Willis, R.P. 1972 The Exporting Firm: Structure, Policy, Personnel and Performance. Unpublished MA Thesis V.U.W. Geography Department.

Willis, R. 1982 Industrial Restructuring: A Comparison of New Zealand and the Motherlands in the post war period. Proceedings of the New Zealand Geography conference 1981. New Zealand Geographical Society, Wellington : 78-82.

Willis, R.P. 1993 Employment Change in Manufacturing Australia Vs New Zealand 1987-1992. In Morrison, P.S. (ed.) Labour Employment and Work in New Zealand. Proceedings of the fifth conference, Department of Geography, Victoria University of Wellington Wellington : 23-28.

Wooding, P. 1987 Liberalising the Internal Trade Regime. In Bollard, A., and Budde, R. (Eds)
Economic Liberalisation in New Zealand. Oxford University Press, Auckland : 86-101.

\section{Author}

Richard Willis is a Senior Lecturer in Geography at Victoria University of Wellington, PO Box 600 , Wellington. 